\title{
11
}

\section{The rise and fall of the genus Araucario: A Southern Hemisphere climatic connection}

\author{
Marie-Pierre Ledru \\ Institut de Recherche pour le Développement, Institut des Sciences de l'Evolution de Montpellier, \\ Université de Montpellier 2, France \\ marie-pierre.ledru@ird.fr
}

Janelle Stevenson

The Australian National University, Canberra, ACT

\section{Introduction}

Understanding tropical sensitivity and its link with higher latitudes is a major issue for both climatologists and climate modellers. Moreover, changes in the floristic composition of tropical forests through time are of interest to ecologists wanting to understand the evolution of tropical biodiversity. Araucariaceae is a very ancient family of conifers dating to the Triassic. Its maximum diversity was reached during the Jurassic and Cretaceous periods, becoming extinct in the Northern Hemisphere at the end of the Cretaceous. Today, the genus Araucaria includes 19 species, 13 of which are endemic to New Caledonia, with another six distributed across Norfolk Island, eastern Australia, New Guinea, Argentina, Chile and southern Brazil (Enright and Hill 1995; Kershaw and Wagstaff 2001).

Among these 19 Southern Hemisphere species of Araucaria, five are endangered and three have a vulnerable status (UICN). All species have restricted distributions, which are relicts of a past expansion. These large trees, with a massive central trunk that commonly reach heights of 30-60 m, are mainly restricted to moist forests in the wet cool tropics (Figure 1) with a mixed lower strata of angiosperms. When temperatures are high, as in New Guinea or near Rio de Janeiro in Brazil, Araucaria grows at higher elevation (Kershaw and McGlone 1995).

Araucaria forest expansion and contraction during the last glacial/interglacial cycle is recorded in three long pollen records, all at a similar latitude: southern Brazil, northeastern Australia and New Caledonia. In northeastern Australia, at Lynch's Crater on the Atherton Tableland, the pollen record extends back 230,000 years and shows that rainforest expansion took place during wetter interglacial periods, replaced by drier rainforest and sclerophyll vegetation during drier glacials. The expansion of Araucaria forest is seen twice in this record, from ca. 190,000-130,000 years ago and from 80,000-45,000 years ago (Kershaw et al. 2007). 


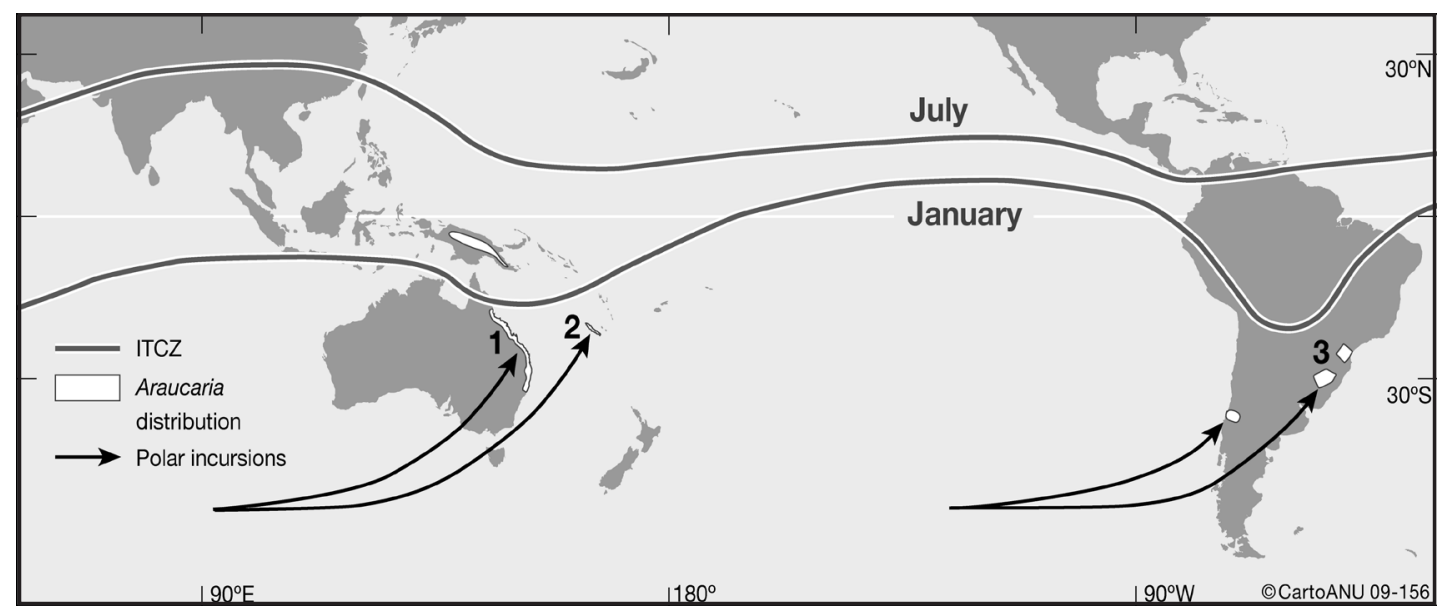

Figure 1. Modern distribution of Araucaria in the Southern Hemisphere (from Enright and Hill 1995), trajectories of the polar advections (black arrows) towards the continents, northern and southern extent of the Inter Tropical Convergence Zone (ITCZ) and localities of the palaeorecords: 1) Lynch's Crater, 2) Lake Xere Wapo, 3) Colônia Crater.

The disappearance of Araucaria at 45,000 years ago, synchronous with an increase in fire and a shift towards open sclerophyllous forest or savanna, was attributed to the burning activities of people in the absence of any significant change in global climate cyclicity (Kershaw 1978, 1986). The comparative marine record off the northeast Australian coast, ODP 820, illustrates that at a regional scale there was a trend of decreasing Araucaria pollen and increasing pollen from sclerophyll taxa over the past 250,000 years (Moss and Kershaw 2007), and attests to the continuous presence of fires in the broader landscape for the past 250,000 years. It is thought, therefore, that what are seen at 45,000 years ago in the Lynch's Crater record are changes that were already in motion before the human colonisation of Australia, but that these changes were accelerated by human impact (Kershaw et al 2007). Detected in both the Lynch's Crater record and the ODP 820 record is a non-Milankovitch 30,000-year frequency that is present in most major attributes and dominates both gymnosperm and charcoal records (Kershaw et al. 2003, 2007; Moss and Kershaw 2007), and which is thought to represent a modification of the precessional signal due to ENSO variability (Beaufort et al. 2003).

A long comparative record from New Caledonia contains a similar disappearance of Araucaria forest (Stevenson and Hope 2005). However, as this island was only colonised by people 3000 years ago, human disturbance is not a factor in explaining this vegetation change, nor is fire a component of Araucaria decline. As human impact is excluded until the late Holocene, the ENSO hypothesis was retained in spite of some chronological matching uncertainties.

In the pollen record from Colônia Crater in southern Brazil, neither human impact nor ENSO can be inferred to explain the disappearance of Araucaria; human arrival on the South American continent is estimated to be around 12,000 years ago and the site is located on the Atlantic side of the continent where the ENSO phenomenon is weak and dependent on other intrahemispheric linkages (Lau and Zhou 2003). Indeed, a spectral analysis performed on arboreal pollen frequencies from the Colonia Crater record shows only one signal, that of precession (Ledru et al. 2009). In addition, fire was not a driving factor, as no charcoal particles were recovered from the sediments. Consequently, a change in Southern Hemisphere climate is the remnant hypothesis to explain the decline of Araucaria at all three sites 45,000 years ago. In this paper, we explore this phenomenon in an attempt to establish the major contributing factor to Araucaria expansion and contraction during the late Quaternary. 


\section{Climate control on the modern distribution and composition of Araucaria forests}

Australia

In Australasia, five species of Araucaria are observed today; one species is restricted to Norfolk Island, two species are restricted to New Guinea, and two species are in northeastern Australia (A. bidwillii and A. cunninghamii). Both species are found in the cooler subtropical forests of southeast Queensland, but apart from a few isolated occurrences of $A$. bidwilli, all of the araucarian forest patches further north, extending as far as New Guinea, are dominated by $A$. cunninghamii (Kershaw and McGlone 1995; Kershaw and Wagstaff 2001; Kershaw and Walker 2007). While found in the cooler tropical forests of the northeast Queensland's mountain tops, where the short dry season is attenuated by fog and cloud interceptions, A. cunninghamii is also an important emergent in the lowland dry vine forests of southeast Queensland and northern New South Wales, as well as growing on a number of islands off the northeast Australian coast (Enright 1995). The habitat of the species is therefore highly diverse, growing on a variety of substrates both in Australia and New Guinea, under average annual rainfall regimes varying from $850 \mathrm{~mm}$ to $>4000 \mathrm{~mm}$ and in locations with mean annual temperatures from as low as $11^{\circ} \mathrm{C}$ to as high as $26^{\circ} \mathrm{C}$ (Enright 1995 ).

The Australian climate is dominated by the seasonal migration of the subtropical high system, the synoptic scale manifestation of the descending limb of the Hadley circulation (Hobbs 1999). During austral winter, the subtropical highs occupy their most northerly position over the Australian continent. This directs dry easterly trade winds over the north of the continent, while frontal lows embedded within the mid-latitude westerlies are directed over southern Australia, which experiences its wet season. During austral summer, the subtropical highs migrate towards the pole, occupying a position near Australia's southern margin. The subsiding air beneath the anticyclone brings primarily dry summer weather to southern Australia, as the westerlies are pushed south of the continent (Gentilli 1972). At the same time, the Inter Tropical Convergence Zone (ITCZ) moves south of the equator, bringing monsoon rains to Australia's north.

The Atherton region in northeastern Australia has a tropical climate, with an average annual rainfall of $1420 \mathrm{~mm}$. The majority of Atherton's rainfall occurs during summer between December and March, a time when the monsoon trough is close to this region, with the intensity and frequency of rainfall attributed to the location of the ITCZ and the South Pacific Convergence Zone (SPCZ). Eighty percent of the region's precipitation falls during the summer and less than $10 \%$ in winter. However, frequent cloud and drizzle at higher elevations like Lynch's Crater mean that moist conditions are maintained throughout the year. The climate of the Atherton Tableland region is also affected by the ENSO phenomenon, with El Niño phases inducing a strong decrease in seasonal rainfall due to changes in the position of the convergence zones: the ITCZ and the SPCZ.

The prevailing winds at Atherton are east to southeasterly, with the strongest winds (excluding cyclones) occurring during April and August. During the winter months, the region can experience incursions of cooler air brought by westerly winds (Baines 1980) (Figure 1).

\section{Nerw Caledonia}

Of the 13 species that grow in New Caledonia today, 11 grow in the southern massif $\left(22^{\circ} \mathrm{S}\right)$, where topography and altitude ensure that annual rainfall is in excess of $1500 \mathrm{~mm}$ (Jaffré 1995). The southern massif is dominated by an ultramafic geology, resulting in a landscape with a characteristic vegetation type known locally as the maquis minier; a sclerophyllous, evergreen, light-demanding formation associated with ultramafic rocks. This formation can be composed of either shrubs or a woody-herbaceous combination with a dense layer of sedges that may be 


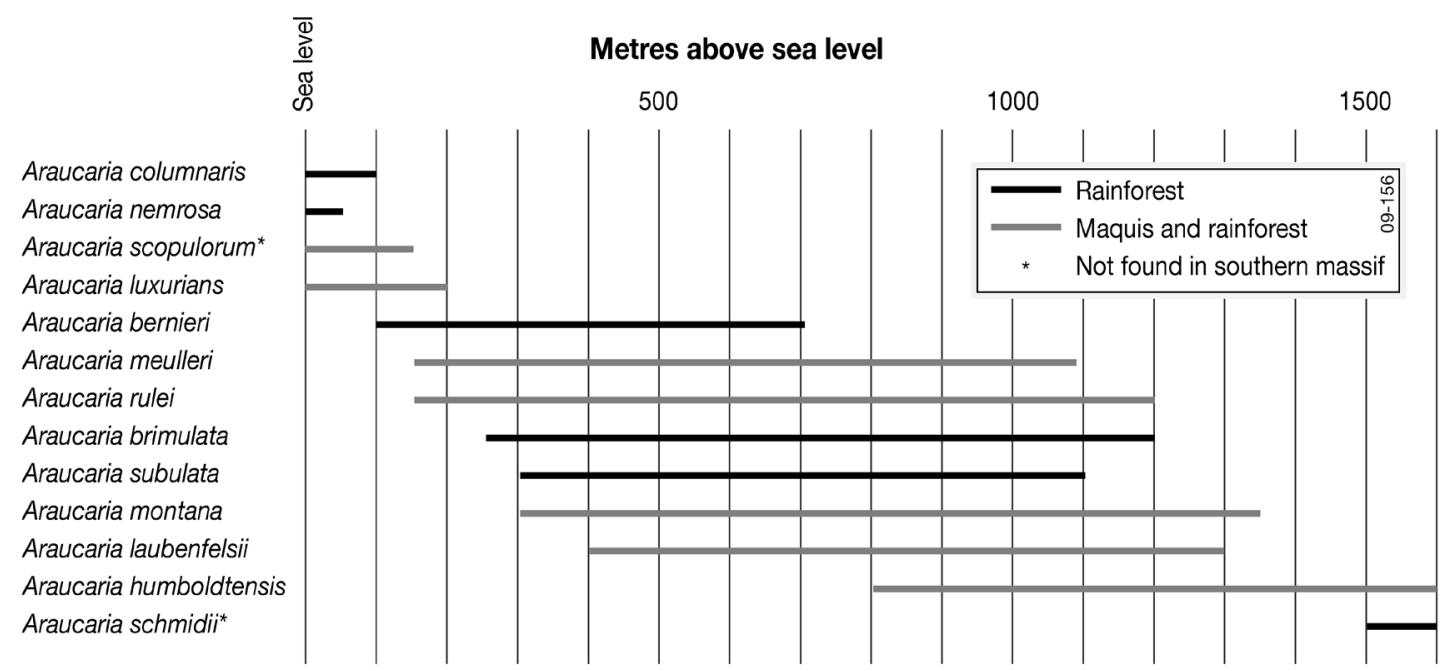

Figure 2. Distribution of the species of Araucaria in New Caledonia.

locally dominated by an arborescent stratum of Araucaria spp. or Agathis ovata. However, within this landscape and on this same substrate can be found complex evergreen rainforest, which also has a significant Araucaria component; Figure 2 illustrates the altitudinal and vegetation associations of the New Caledonian Araucaria. The bulk are found between $100 \mathrm{~m}$ and $1300 \mathrm{~m}$ altitude (seven species), with four restricted to below $200 \mathrm{~m}$, and only one between $1500 \mathrm{~m}$ and $1600 \mathrm{~m}$ (Figure 2, Jaffré 1995).

The climate of New Caledonia is controlled primarily by the southeast trade winds, which in conjunction with the island's topography result in a wet east coast (annual rainfall $>3000$ $\mathrm{mm}$ ) and a much drier west coast (annual rainfall $<1500 \mathrm{~mm}$ ) (Renson 1981). From November to April, the winds become more easterly and tropical depressions from the north dominate. The wettest months are during the warm season, January to March, which receive 57\% of the annual precipitation. The remainder is distributed more or less equally over the other nine months. During the cool season (April to July), precipitation is irregular and occasional intrusions of cold polar air from the westerlies are observed (see Figure 1). These strong, cold winds come up through the Tasman Sea and lead to cool winter rainfall.

\section{South America}

Two species of Araucaria grow today in South America, as opposed to 17 in Australasia (Enright and Hill 1995). In South America, the two species of Araucaria are majestic trees that attain a height of $50 \mathrm{~m}$ and a diameter of $2 \mathrm{~m}$. In southern Brazil, the Araucaria angustifolia forest is located in an area influenced by polar advection, providing moist and cool conditions throughout the year (Ledru 1993). In Chile, Araucaria araucana almost disappeared due to the intensive logging of past decades, and now shows a patchy distribution (Veblen et al. 1995). However, it grew in the cool and moist temperate regions of central Chile, at high elevations near the coast or deeper inland. No pollen records have ever been studied within the Chilean araucaria forest. This zone is under the influence of the westerlies from the southwestern Pacific, bringing regular precipitation throughout the year (Figure 1) (Garreaud 2000).

Cold surges are among the most energetic influences on the tropical circulation by the extratropics, with surface topography playing a central role, as shown by both observation and simulation (Markgraf 2001). In the absence of a significant mountain range, as in southern South America, cold surges are not deflected equatorward, but rather continue eastward. Key elements in the South American scenario are the cold anticyclones that move from the southeastern Pacific into southern Argentina and a centre of low pressure that deepens in the 
southwestern Atlantic. The advance of the cold-air incursion along the subtropical Andes is set up by the topographic blocking of the synoptic-scale flow. The strong temperature gradient produces the acceleration of the low-level winds parallel to the Andes range. This is a wellknown extreme and abrupt event in Brazil that can damage the coffee plantations (Hamilton and Tarifa 1978).

In Brazil, Araucaria angustifolia grows at high elevations between $1500 \mathrm{~m}$ and $1800 \mathrm{~m}$ near Rio de Janeiro $\left(20^{\circ} \mathrm{S}\right)$ or between $500 \mathrm{~m}$ and $900 \mathrm{~m}$ in the subtropics, latitude $25^{\circ} \mathrm{S}$ to $30^{\circ} \mathrm{S}$. In the subtropical area, an expansion of Araucaria angustifolia occurred during the past 1000 years from refugia located either in the gallery forest or in the vicinity of a water source (Behling 1997a, b; Bitencourt and Krauspenhar 2006). The existence of these forests in southern Brazil is determined by the modern climate and the mean position of the polar fronts during winter, providing permanent drizzle (Ledru et al. 1994). The climate of this area is characterised by the absence of a dry season due to frequent and intense shifts of the polar fronts, providing regular fog and cloud cover in winter, along with low temperatures and occasional frost (Ledru 1993; Marengo et al. 1997; Garreaud 2000, 2001). While in the mountain range near Rio de Janeiro, the same phenomenon is induced by the uplift of warm Atlantic Ocean moisture, leading to almost continuous cloud cover and cooler temperatures, with the Araucaria forest assimilated into a cloud forest formation at higher altitude.

\section{Araucaria forest expansion during the last glacial}

\section{Lynch's Crater, northeastern Australia}

Lynch's Crater (17 $\left.37^{\prime} \mathrm{S}, 145^{\circ} 70^{\prime} \mathrm{E}\right)$ lies at an altitude of about $760 \mathrm{~m}$ above sea level (asl). Human activities over recent decades have destroyed much of the swamp surface and the main vegetation in the crater today is composed of introduced pasture species. A complex rainforest dominates the regional landscape with different facies according to location, drainage and rainfall distribution - from mesophyll vine forest, mesophyll palm forest, Melaleuca open woodland, to notophyll and microphyll vine forests. More open woodland with species of Eucalyptus is related to edaphic and topographic conditions. The crater is approximately $500 \mathrm{~m}$ in diameter, with recovered deposits extending to $64 \mathrm{~m}$ in depth and consisting mainly of lake muds, except for the top $14.5 \mathrm{~m}$, where they are replaced by fresh to oxidised swamp sediments.

The pollen record contains two glacial-interglacial cycles, with 11 major changes in the composition of the rainforest (Kershaw 1978, 1986; Moss and Kershaw 2000; Kershaw et al. 2003, 2007). Although not illustrated in Figure 3, Araucaria frequencies are high between ca. 170,000 and 130,000 years ago. From 130,000 to 80,000 years ago, they are low, with a median value of less than $2 \%$. During this time, rainforest angiosperms dominate the pollen spectrum, with the pollen of Araucaria virtually disappearing just before 80,000 years ago. High values are once again observed between ca. 80,000 and 45,000 years ago, with a median of $9.5 \%$ over 42 samples. The pollen frequency of Araucaria then suddenly declines at 45,000 years ago, coincident with an increase in charcoal particles. A short and weak return of Araucaria pollen to the record is observed at around 17,000 years ago.

\section{Lake Xere Wapo, New Caledonia}

Lake Xere Wapo (22017.5'S, $\left.166^{\circ} 58.5^{\prime} \mathrm{E}\right)$, at an altitude of $220 \mathrm{~m}$, is located on the Plaine des Lacs, within the southern massif, where the average annual rainfall is $3000 \mathrm{~mm}$. Here, the local climate is controlled largely by topography, with rain or fog occurring above $200 \mathrm{~m}$ on most afternoons, even during the dry season.

This shallow lake is approximately $0.85 \mathrm{~km}^{2}$ in area and surrounded by gentle slopes that are mostly covered in a ferritic soil mantle, in places characterised by an iron pan crust known as 
'sols cuirasse'. The surrounding vegetation is a bushy maquis dominated by either Gymnostoma deplancheanum or Dacrydium araucarioides. Five species of Araucaria are found at this altitude within the Plaines des Lacs, but not in the immediate vicinity of the lake.

Establishing a robust chronology for Lake Xere Wapo has been difficult, but based on the best model produced so far, three main phases are observed in the Araucaria pollen frequencies (Stevenson and Hope 2005). Between ca. 130,000 and ca. 80,000 years ago, the landscape moved between forest and maquis fairly frequently, with fire important in both landscapes, although more abundant during times of maquis dominance. The median value of Araucaria during this period is $2.2 \%$, with two outliers of $12 \%$ and $8 \%$.

From ca. 80,000 years ago to possibly 45,000 years ago, the pollen frequencies suggest Araucaria was more dominant in the landscape surrounding Lake Xere Wapo, however fire remained an integral part of the ecology. The median value of Araucaria pollen during this time is $7.5 \%$, with four of the 13 samples being above $10 \%$.

The most profound changes in the record occur after 45,000 years ago to the present, when Araucaria pollen frequencies fall to their lowest levels, with a median value of $0.9 \%$ and with only three of the 19 samples having values greater than $2 \%$. Of note is that this change occurred in the absence of fire, suggesting that other forms of disturbance, such as an increase in climate variability, may be responsible (Stevenson and Hope 2005).

\section{Colônia Crater, Brazil}

Colônia is a meteor crater $3.5 \mathrm{~km}$ in width, filled with $392 \mathrm{~m}$ of organic sediments, located within the city of São Paulo (2352'S, 46 42’20”W, $900 \mathrm{~m}$ asl). Its location near the Atlantic Ocean and in the Sierra do Mar mountain range means the vegetation is highly sensitive to changes in sea level and temperature. Today, the climatic features of the Colônia region are characterised by a mean annual precipitation of $1700 \mathrm{~mm}$, a mean winter temperature of ca. $15^{\circ} \mathrm{C}$ and a three-month winter dry season.

There are no Araucaria forests in the vicinity of Colônia today. Only single trees of Araucaria angustifolia are observed in a landscape dominated by semi-deciduous Atlantic rainforest. Compared with the Araucaria pollen frequencies of Australia and New Caledonia, here the frequencies that indicate Araucaria within the landscape are an order of magnitude lower. This is in part related to Araucaria being, in general, a low pollen producer with large grains that are poorly dispersed. Consequently, pollen remains mostly in the vicinity of the source, leading to relatively low frequencies in pollen records, with pollen rain studies revealing ratios of up to $80 \%$ under the tree cover, to a single grain in the middle of a mire surrounded by Araucaria forest (Ledru 2002).

The Colônia record, as illustrated in Figure 3, has four main pollen zones in Araucaria pollen frequency. All eight samples from the tail end of MIS 6, 135,000-130,000 years ago, contain Araucaria pollen; these are also the highest frequencies for the entire record. Only two out of the next 10 samples that cover the last interglacial, 130,000-120,000 years ago, have Araucaria pollen, and from ca. 120,000 to 80,000 years ago, only 15 samples, out of a total of 56 samples, contain Araucaria pollen grains. However, there is a shift between ca. 80,000 and 60,000 years ago, with 22 samples out of a total of 35 containing Araucaria pollen grains. From 60,000 to 40,000 years ago, the presence of Araucaria declines, with only seven samples out of 35 containing Araucaria pollen grains. The past 40,000 years record the lowest frequencies of arboreal pollen in general, along with the disappearance of Araucaria. Only two samples out of 73 have Araucaria pollen - between ca. 18,000 and 16,000 years ago, at the end of the glaciation (Ledru et al. 2009). 

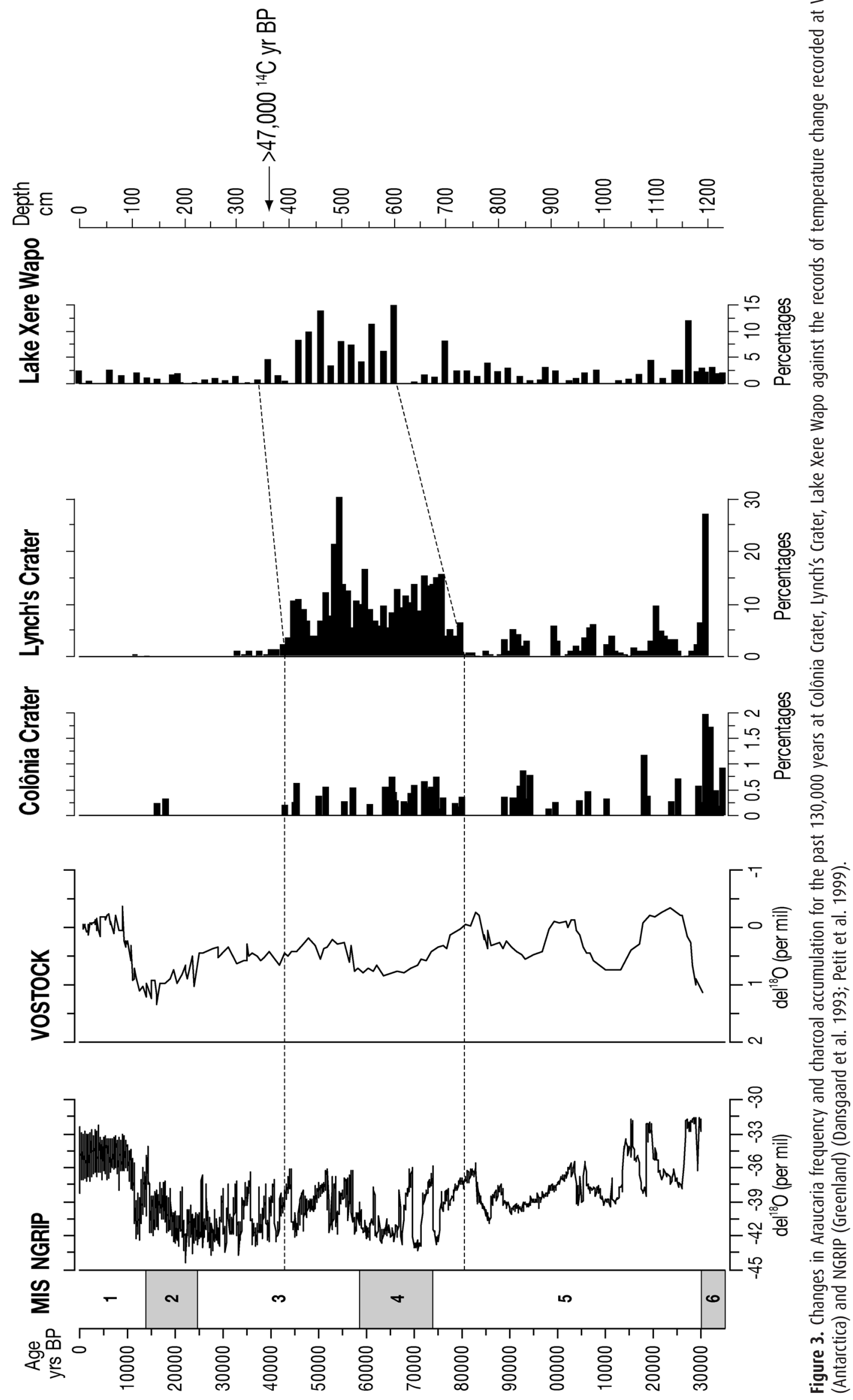


\section{Discussion}

Between 85,000 and 60,000 years BP, a drastic drop in temperature is observed in Antarctic ice cores (Figure 3), characterised by ice expansion and lowering of sea level by $70 \mathrm{~m}$ (Shackleton 1987; Petit et al. 1999). Climatic reconstructions for this period suggest that moisture in the tropics was provided by a steep temperature gradient between the southern latitudes and the equator (Vimeux et al. 1999; Delaygue et al. 2000), with the overall result being, relative to present, a change in the frequency and intensity of northward moving polar advections, which induced a shift of the winter rainfall zone.

The modern climate in the three studied areas (northeastern Australia, southwestern Pacific and southeastern Brazil) is primarily directed by the seasonal interplay between the subtropical high-pressure cells and the migration of the easterlies associated with the ITCZ, resulting in summer rainfall and a dry winter. However, the dry winter season can be attenuated by a northward shift of the westerlies, with the three study regions today subjected to abrupt, short and extreme climatic events brought about by this equatorward migration of polar air masses (Garreaud 2000, 2001). The signature of the cold surges over the tropics is much clearer in South America than in Australia, mainly as a consequence of favourable topography, specifically the narrow and tall Andean Cordillera, which extends continuously from south to north, providing an ideal barrier to channel these surges northward. In Brazil and Chile, the location of Araucaria forest today is defined by the intensity and frequency of these polar advections, and where winter rainfall is reliable.

The chronology of the three pollen records presented here is limited by the range of the radiocarbon method (ca. 40,000 years). Where possible, empirical methods of chronological reconstruction were used, such as precession-cycle-based tree maxima at Colônia Crater, or matching with nearby marine cores, such as at Lynch's Crater. Therefore, the time intervals that are discussed are not definitive and are subject to refinement with improvements in dating methods and/or the increase of comparable palaeoclimatic records. While taking this qualification into account, the changes in Araucaria at this stage appear synchronous (Figure 3). These three sites in three different regions of the Southern Hemisphere show the same directional change. Before 130,000 years ago, Araucaria frequencies are high, falling as the record enters the last interglacial (130,000-120,000 years ago). Between 120,000 and 80,000 years ago, Araucaria pollen frequencies decreased or were not represented at all in samples. Between 80,000 and 40,000 years ago, a full expansion of Araucaria forest is observed around Lynch's Crater and Lake Xere Wapo, with a more consistent presence recorded in the Colônia Crater record between 80,000 and 60,000 years ago. The pollen record of Colônia shows a progressive contraction of Araucaria forest after 60,000 years ago until its disappearance shortly after 40,000 years ago, while in Australia and New Caledonia, the frequencies of Araucaria pollen started to decrease shortly before 40,000 years ago. A last short increase in Araucaria pollen frequencies is observed during the late glacial at Colônia and at Lynch's Crater, while they remain low and constant up to the present at Lake Xere Wapo. The higher pollen frequencies between 80,000 and 40,000 years ago at Lynch's Crater and Lake Xere Wapo suggest that Araucaria was dominant in these landscapes, and that the summers were cooler and winters moister than in the preceding time interval.

Keeping in mind the uncertainty of the chronology, the major expansion phase of Araucaria between ca. 80,000 and 60,000 years ago may be linked to the corresponding cold stage 4 (76,000-62,000 years ago). While the role of human activity in the subsequent decline of Araucaria at 45,000 years ago at Lynch's Crater may still be under debate, we know that with the late arrival of people in South America (ca. 12,000 years ago) and New Caledonia (ca. 3000 years ago), human impact is not a component in these landscapes. Consequently, global 
climatic change is the most likely driver of this common feature in the three records.

Indeed, studies from Brazil suggest that the westerly storm track migrated northward several times during the late glacial, each time favouring the development of Araucaria at a different latitude. These records lack the time depth of Colônia Crater, but suggest that Araucaria forests were modified several times over the past 20,000 years. For instance, Araucaria forest is observed at $19^{\circ} \mathrm{S}$ at 15,000 years ago (Ledru 1993), at $23^{\circ} \mathrm{S}$ at 17,000 years ago (Ledru et al. 2009), and at $25^{\circ} \mathrm{S}$ today (Ledru et al. 1994). These shifts have been interpreted as a response to increased winter precipitation and a strongly reduced winter dry season (Ledru et al. 1994). The mechanism for this has been put forward as the weakening and poleward shift of the westerlies, giving more space to the tropical easterlies and the ITCZ seasonal shifts, which results in a summer rainfall regime (Ledru et al. 1994).

The phases of expansion and retraction of the Araucaria forests of the Southern Hemisphere provide a good bio-indicator for detecting change in the tropical hydrological system. In other southern regions where no Araucaria forests are observed today, palaeorecords that cover late MIS 5 to MIS 3 with a similar length and resolution are scarce. However, in South Africa, hyrax middens and a marine record, MD962094, attest to a cooler and moister climate between late MIS 5 and MIS 4. The increase in precipitation observed in these records has been related to Antarctic ice expansion and a northward shift of the westerlies band track between ca. 86,000 and 59,000 years ago (Stuut et al. 2002; Chase and Meadows 2007; Chase 2010). The termination of this moist and cool phase has been interpreted as a poleward shift of the westerlies, with an associated decrease in winter precipitation (Chase 2010). Further evidence in support of this scenario comes from the interior of Australia. Research into the palaeohydrology of Australia's mega-lakes, in combination with other palaeoclimatic proxies, has concluded that while there were multiple sources of precipitation leading to the formation of these lakes over the last glacial cycle, Southern Ocean sources of precipitation were an integral component until 47,000 years ago (Cohen et al. 2011). After this time, there is evidence from shoreline data and other palaeoclimatic data for increasing aridification and a decreasing contribution of moisture from Southern Ocean sources (Cohen et al.2011), the time period that sees the contraction of Araucaria in the Lynch's Crater record.

In the equatorial Pacific, changes in sea surface temperatures of between $2^{\circ} \mathrm{C}$ and $3.5^{\circ} \mathrm{C}$ at 70,000 years ago precede change in Northern Hemisphere ice volume by 3000 years (Lea et al. 2006). In addition, deuterium analyses of an Antarctic ice core (Vostok) showed that the obliquity cycle, which controls insolation at $60^{\circ} \mathrm{S}$, induced strong changes on both atmospheric and ocean circulations during cold stages 2, 4 and 6 (Vimeux et al. 1999).

Therefore, we suggest that during MIS 4, the rainfall environment that favoured an expansion of Araucaria in the southern tropics might have contributed to the observed increase in snow accumulation in Antarctica. This hypothesis is further supported by models (NASA/ GIS AGCM) which show that present-day moisture sources for Antarctica originate in the subtropics and mid-latitudes of the Southern Hemisphere and from the intertropical zone during the Last Glacial Maximum (Delaygue et al.2000). Our results suggest that this moisture was mostly distributed from the latitudinal band comprising (at least) $16^{\circ} \mathrm{S}$ to $23^{\circ} \mathrm{S}$ during stage 4 and the early part of stage 3 . This was made possible because of a northward shift of the westerlies band track over the southern tropics, with the progressive decline in Araucaria after 45,000 years ago most likely the consequence of a reorganisation of the ocean-atmosphere forcing in the Southern Hemisphere. 


\section{Conclusion}

In spite of the difficulties in establishing reliable chronologies, the simultaneous presence and expansion of Araucaria within the three study areas, located between $19^{\circ} \mathrm{S}$ and $23^{\circ} \mathrm{S}$, and composed of two fragments of Gondwana, attest to a similar response to Southern Hemisphere climatic changes and an equal reaction of the species to the installation of a permanent cool and wet climate between at least 80,000 and 40,000 years ago. Consequently, we suggest a Southern Hemisphere climatic cause, rather than a human or ENSO-based scenario, to explain the decline of the Araucaria at these three sites.

It is hypothesised that the strong cooling in Antarctica that induced the shift of the westerly band tracks towards the equator between 86,000 and 60,000 years ago strengthened the winter rainfall system and thus lead to an expansion of Araucaria across the Southern Hemisphere subtropics. However, after 40,000 years ago, the poleward shift of the westerlies band, in combination with the intensification of the northern circulation and the ITCZ seasonal shifts on the distribution of precipitation in the tropics, resulted in weaker and less frequent northward polar advections, which had profound consequences for Araucaria forests in northern Australia, New Caledonia and Brazil. The consequent dominance of an easterly circulation system induced a drier winter season at low latitudes, causing the decline of Araucaria in the tropics, with forests only surviving in regions where cloud cover or winter rains meet their needs. In some southern tropical regions, a last tropical expansion of the Araucaria was observed during the late glacial, approximating the Antarctic Cold Reversal, when abrupt and short climatic changes were induced by strong differences between Northern and Southern Hemisphere temperature gradients (Broecker 1998; Stocker 2003).

While this synthesis illustrates how vulnerable this ancient tree is without suitable protection of its current remnant distributions, it also provides an interesting hypothesis for the past importance of the westerlies in the Southern Hemisphere hydrologic cycle, a topic of interest to fully understand the potential impacts of climate change on tropical environments and of the contribution of southern low-latitude moisture on Antarctic ice-expansion phases.

\section{Acknowledgements}

Thanks to Peter Kershaw for having created and stimulated the Southern Connections meetings and post meetings within the palynological community. We also thank two anonymous referees for their constructive discussion and comments.

\section{References}

Baines, P.G. 1980. The dynamics of the southerly buster. Australian Meteorological Magazine 28:175-200.

Beaufort, L., de Garidel-Thoron, T., Linsley, B., Oppo, D. and Buchet, N. 2003. Biomass burning and oceanic primary production estimates in the Sulu Sea area over the last 380 kyr and the East Asian monsoon dynamics. Marine Geology 201:53-65.

Behling, H. 1997a. Late Quaternary vegetation, climate and fire history from the tropical mountain region of morro de Itapeva, SE Brazil. Palaeogeography Palaeoclimatology Palaeoecology 129:407-422.

Behling, H. 1997b. Late Quaternary vegetation, climate and fire history of the Araucaria forest and campos region from Serra Campos Gerais, Paraná state (South Brazil). Review of Palaeobotany and Palynology 97:109-121.

Bitencourt, A.L.V. and Krauspenhar, P.M. 2006. Possible prehistoric anthropogenic effect 
on Araucaria angustifolia (Bert.) O. Kuntze expansion during the Late Holocene. Revista Brasileira de Paleontologia 9:109-116.

Broecker, W.S. 1998. Paleocean circulation during the last deglaciation: A bipolar seesaw? Paleoceanography 13:119-121.

Chase, B.M. and Meadows, M.E. 2007. Late Quaternary dynamics of Southern Africa's winter rainfall zone. Earth-Science Reviews 84:103-138.

Chase, B.M. 2010. South African palaeoenvironments during Marine Oxygen Isotope stage 4: a context for the Howiesons Poort and Still Bay industries. Journal of Archaeological Science 37:1359-1366.

Cohen, T.J., Nanson, G.C., Jansen, J.D., Jones, B.G., Jacobs, Z., Treble, P., Price, D.M., May, J.-H., Smith, A.M., Ayliffe, L.K. and Hellstrom, J.C. 2011. Continental aridification and the vanishing of Australia's megalakes. Geology 39:167-170.

Delaygue, G., Masson, V., Jouzel,J. and Koster, R.D. 2000. The origin of Antarctic precipitation: a modelling approach. Tellus 52B:19-36.

Dansgaard, W., Johnsen, S.J., Clausen, H.B., Dahljensen, D.S., Gundestrup, N., Hammer, C.U., Hviberg, C.S., Steffensen, J.R., Sveinbjörnsdottir, A.E., Jouzel, J. and Bond, G. 1993. Evidence for general instability of past climate from a 250-kyr ice core record. Nature 364:218-220.

Enright, N.J. and Hill, R.S. 1995. Ecology of the Southern conifers. Melbourne University Press, $342 \mathrm{pp}$.

Enright, N.J. 1995. Conifers of Tropical Australia. In: Enright, N.J. and Hill, R.S. (eds), Ecology of the Southern conifers, pp. 197-222. Melbourne University Press.

Garreaud, R.D. 2000. Cold air incursions over subtropical South America: mean structure and dynamics. Monthly Weather Review 128:2544-2559.

Garreaud, R.D. 2001. Subtropical cold surges: regional aspects and global distribution. International Journal of Climatology 21:1181-1197.

Gentilli, J. 1972. Australian climate patterns. Nelson, Melbourne, 285 pp.

Hamilton, M.G. and Tarifa, J.R. 1978. Synoptic aspects of a polar outbreak leading to frost in tropical Brazil, July 1972. American Meteorological Society 106:1545-1556.

Hobbs, J.E. 1999. Present climates of Australia and New Zealand. In: Hobbs, J.E., Lindesay, J.A. and Bridgman, H.A. (eds), Climate of the Southern Continents: Present, Past and Future, pp. 63-105. Wiley and Sons, Chichester.

Jaffré, T. 1995. Distribution and Ecology of the Conifers of New Caledonia. In: Enright, N.J. and Hill, R.S. (eds) Ecology of the Southern conifers, pp. 171-196. Melbourne University Press, Melbourne.

Kershaw, A.P. 1978. Record of last interglacial-glacial cycle from northeastern Queensland. Nature 272:159-61.

Kershaw, A.P. 1986. Climatic change and aboriginal burning in North-East Australia during the last two glacial/interglacial cycles. Nature 322:47-9.

Kershaw, A.P. and McGlone, M.S. 1995. The Quaternary of the southern conifers. In: Enright, N.J. and Hill, R.S. (eds), Ecology of the Southern conifers, pp. 30-63. Melbourne University Press, Melbourne, Australia.

Kershaw, A.P. and Wagstaff, B. 2001. The southern conifer family Araucariaceae: history, status and value for paleoenvironmental reconstruction. Annual Revierws of Ecology and Systematics 32:397-414.

Kershaw, A.P., van Der Kaars, S. and Moss, P.T. 2003. Late Quaternary Milankovitch-scale climatic change and variability and its impact on monsoonal Australasia. Marine Geology 201:81-95.

Kershaw, A.P. and Walker, D. 2007. Quaternary vegetation and environments of the North- 
East Queensland volcanic provinces. XVII INQUA Cairns 2007 Post Excursion B2 guide. Monash University, 128 pp.

Kershaw, A.P., Bretherton, S.C. and van der Kaars, S. 2007. A complete pollen record of the last 230 ka from Lynch's Crater, north-east Australia. Palaeogeography, Palaeoclimatology, Palaeoecology. 25:23-45.

Lau, K.-M. and Zhou, J.2003. Anomalies of the South American summer monsoon associated with the 1997-99 El Niño-southern oscillation. International Journal of Climatology, 23:529-539.

Lea, D.W., Pak, D.K., Belanger, C.L., Spero, H.J., Hall, M.A. and Shackleton, N.J. 2006. Paleoclimate history of the Galapagos surface waters over the last 135,000 yr. Quaternary Science Revierws 25:1152-1167.

Ledru, M.-P. 1993. Late Quaternary environmental and climatic changes in central Brazil. Quaternary Research 39:90-98.

Ledru, M.-P. 2002. Late Quaternary history and evolution of the Cerrados as revealed by palynological records. In: Oliveira, P.S. and Marquis, R.J. (eds), The Cerrados of Brazil: Ecology and natural history of a neotropical savanna, pp. 33-52. Columbia University Press, New York.

Ledru, M.-P., Behling, H., Fournier, M., Martin, L. and Servant, M. 1994. Localisation de la forêt d'araucaria du Brésil au cours de l'Holocène. Implications paléoclimatiques. Comptes Rendus de l'Académie des Sciences de Paris 317:517-521.

Ledru, M.-P., Mourguiart, P. and Riccomini, C. 2009. Related changes in biodiversity, insolation and climate in the Atlantic rainforest since the last interglacial. Palaeogeography, Palaeoclimatology, Palaeoecology 271:140-152.

Marengo, J.A., Cornejo, A., Satyamurty, P., Nobre, C. and Sea, W. 1997. Cold surges in tropical and extratropical South America: The strong event in June 1994. Monthly Weather Review 125:2759-2786.

Markgraf, V. (ed) 2001. Interhemispheric Climate Linkages. Academic Press, 488 pp.

Moss, P.T. and Kershaw, A.P.2000. The last glacial cycle from the humid tropics of northeastern Australia: comparison of a terrestrial and a marine record. Paleogeography, Palaeoclimatology, Palaeoecology 155:155-176.

Moss, P.T. and Kershaw, A.P. 2007. A late Quaternary marine palynological record (oxygen isotope stages 1 to 7) for the humid tropics of northeastern Australia based on ODP Site 820. Paleogeography, Palaeoclimatology, Palaeoecology 251:4-22.

Petit, J.-R., Jouzel, J., Raynaud, D., Barkov, N.I., Barnola, J.-M., Basile, I., Bender, M.L., Chappellaz, J., Davis, M.E., Delaygue, G., Delmotte, M., Kotlyakov, V.M., Legrand, M., Lipenkov, V.Y., Lorius, C., Pépin, L., Ritz, C., Saltzman, E. and Stievenard, M. 1999. Climate and atmospheric history of the past 420,000 years from the Vostock ice core, Antarctica. Nature 399:429-436.

Renson, S. 1981. Le Climat de la Grand Terre et des Iles. In: Mathieu-Daudé, J. (ed), Atlas de Nouvelle Calédonie. Editions du Cagou, Hatchette Calédonie, New Caledonia, 92 pp.

Shackleton, N.J. 1987. Oxygen isotopes, ice volume and sea level. Quaternary Science Reviews 6:183-190.

Stevenson, J. and Hope, G. 2005. A comparison of Late Quaternary forest changes in New Caledonia and Northeastern Australia. Quaternary Research 64:372-383.

Stocker, T.F. 2003. South dials North. Nature 424:496-499.

Stuut, J.-B.W., Prins, M.A., Schneider, G.J., Weltje, J.H.F., Jansen, G. and Postma, A. 2002. A $300 \mathrm{kyr}$ record of aridity and wind strength in Southwestern Africa: Inferences from grainsize distributions of sediments on walvis ridge, SE Atlantic. Marine Geology 180:221-233. Veblen, T.T., Burns, B.R., Kitzberger, T., Lara, A. and Villalba, R. 1995. The ecology of the 
conifers of Southern South America. In: Enright, N.J. and Hill, R.S. (eds), Ecology of the Southern conifers, pp. 120-155. Melbourne University Press, Melbourne, Australia.

Vimeux, F., Masson, V., Jouzel, J., Stievenard, M. and Petit, J.R. 1999. Glacial-interglacial changes in ocean surface conditions in the Southern Hemisphere. Nature 398:410-412. 